\title{
Transnationalising “Anti-Popery":
}

\section{Militant Protestant Preachers in the Nineteenth-Century Anglo-World}

During the nineteenth-century, the English-speaking world-Britain, the colonies, and the United States-shared many cultural characteristics. Anti-Catholicism of varying degrees of stridency was one of them. Antipathy towards "Rome" and "Popery" dated to the Reformation and was ingrained in British culture before British and Irish settlers repeopled the colonies. Even as late as the nineteenth century, loyalty was measured in some quarters in religious terms with a rejection of Catholicism forming an important

plank of British identity. ${ }^{1}$ Migration transplanted these and other features of belonging so that even Australia and New Zealand-which took pride in utopian opposition to prejudicial dogma — could still connect with the darker seams of Reformation antipathies when these were laced with anxiety about mass immigration and rapid social change. ${ }^{2}$ Centuries-old prejudice received renewed impetus by mass Catholic migrations from Ireland to all parts of the Anglo-world. Whilst liberties grew and mass urban societies emerged, popular forms of anti-Catholicism also increased to a pitch hitherto unseen since London's Gordon Riots of 1780. Catholic Emancipation (1829), the Maynooth Grant (1845), and the "Papal Aggression" (1850) each produced waves of antagonism in Britain and the ripples were felt in the colonies too. ${ }^{3}$

This article concerns a collection of religious lecturers who were militantly Protestant agents of popular varieties of anti-Catholicism. Such men developed a system of "no popery" public performance that, as well as fostering turbulence and tensions, 
became so lucrative that it produced the revenues necessary for prodigious tours crisscrossing countries, oceans and continents. The Creole demagogue from Demerara, John Sayers Orr, lectured in Scotland, England, the US as well as in his homeland. The Quebecois ex-priest, Pastor Charles Chiniquy, spoke across Canada and the US, made many trips to Britain (especially Scotland) and also embarked on one long sojourn to Australasia. Three of the most extraordinary characters - the soi-disant Baron de Camin, the Italian ex-monk, Giacinto Achilli, and the former priest, also an Italian, Alessandro Gavazzi-spoke in England, Scotland, Ireland and in various places in the US and Canada. ${ }^{4}$

This discussion suggests religious intolerance reflected a certain common Angloworld culture - a sharing of something seamier and less agreeable than the more noble ideologies and activities that Britons and the Irish carried around the globe. ${ }^{5}$ The article offers a series of transnational examinations of what was a curious blend of populist theatre and ribald ideology. ${ }^{6}$ Important scholarship, such as Wolffe's work on both Atlantic world religious identities and British imperial anti-Catholicism, helps frame what follows. ${ }^{7}$ It should also be borne in mind that these preachers were building on common traditions of communication wherein the lecture was a standard vehicle of delivery as well as on a specific established market for religious lectures, not all of them scurrilous or low-grade. ${ }^{8}$

The article draws attention to these peripatetic anti-Catholic preachers as expressions of a darker, more disturbing shared, Anglo-word culture. Though they have been recognised before-especially by scholars of militant Protestantism and popular anti-Catholicism - their transnational dimensions have not been fully explored. ${ }^{9}$ Mass 
newspaper digitisation projects bringing millions of pages of text together in searchable form enable such research by allowing us to join the dots and tease out patterns as the preachers plied their trade. What we find, in all cases, are tensions shaped by several factors. First, that the preachers themselves had colourful and dubious pasts and were far from upstanding members of society. Secondly, that they rode waves of emotion and opportunity offered by the context of a growing, changing cultural and religious landscape. Thirdly, that a focus on gendered controversies - particularly the vow of celibacy and the allegedly sexual prurience of the confessional-greatly increased interest in what they had to say. Fourthly, that the civic authorities and the police generally supported their right to speak, despite the threat of large-scale violence. ${ }^{10}$ The final variable was the role of Irish Catholics as ever-present "mob" (as they were universally dubbed) resisting the preachers in the hope of aborting their lecturers. Not a single riot or interruption described here did not involve the work of organised Irish workingmen hell bent on protecting the reputation of their church: on the one hand, Catholics who were often violently opposed to the preachers, and, on the other hand, Orangemen - often, though not exclusively, Irish-who supported, sponsored and protected many of the preachers. This article is concerned not with the semantics of the lectures, but with the way in which men tapped into a spirit of sectarian conflict and religious community that endured the process of migration and re-settlement, in which Ireland and the Irish were of crucial importance. ${ }^{11}$

\section{A World of Change}


The preachers' trade was encouraged by the wider conditions of the age. Mass migration of Irish Catholics was a crucial determining feature, while urban growth and industrialisation encouraged the pressing and colliding of different cultures. Renewed tenets of Protestant fundamentalism — in part a response to growing Catholic power-also intensified the setting. In Ireland, politico-religious traditions took on their now familiar sectarian shape through the 1798 Rising and growing Catholic assertiveness in the 1820s. The emergence of "Orange" and "Green" factions was one offshoot; the millenarian response to popularisations of "Pastorini" prophecies of the overthrow and slaughter of Protestants by Catholics, was another. ${ }^{12}$ While Catholic secret societies were animated by these prophecies, Protestants resorted to Orangeism and fierce anti-Catholicism. ${ }^{13}$

In the wider Anglophone world, these decades witnessed an evangelical revival that swept into Ireland and Britain from the United States. ${ }^{14}$ In Ireland, Catholic power of a non-apocalyptic kind was marked by the rise of Daniel O'Connell's Catholic Association (1823), a stunningly successful mass mobilisation, resulting in the Catholic masses participating in politics for the first time. O'Connell swept to electoral victory in Clare in 1828 but, as a Catholic, could not take his seat in the House of Commons till legislation was enacted to allow it. The Catholic Association campaigned furiously for the necessary liberties. These duly followed, in 1829, amidst a wave of opposition in the form of letters, petitions, mass meetings, and a general discontent among Protestants. ${ }^{15}$ There was little violence but a line had been crossed. The Catholic Irish settling in Britain's towns and cities must have looked on in wonder and fear at the response of both commoner and elite. 
These were the brooding storm clouds preceding a deluge that broke when the Great Famine (1845-50) washed hitherto unimaginable torrents of Irish and Catholic emigrants across the north Atlantic world. The US, Canada, England, Wales and Scotland were all heavily affected by the resulting human flotsam. America's eastern seaboard witnessed an anti-Catholic hysteria intensified by the convergence of epic Irish migration and the early throes of urban and industrial change. ${ }^{16}$ In Britain, where industrialism already was well set, mass migration from Ireland triggered a Catholic renaissance that contained chilling power for Protestants, whose sensitivity and suspicion was disproportionate to any threat. In 1850 , the inevitable and harmless restoration of the papal hierarchy in England and Wales unleashed Protestant hysteria, ${ }^{17}$ and public opinion became heavily and negatively entrenched. Across the country, clerics, politicians and journalists fanned the flames because the threat from Rome was now seen at home as some had already seen it throughout the Empire. As Wesleyan minister, Stephen Kay, told a public meeting in Preston, Lancashire,

Was not the meeting aware that Popery was putting its hand into the colonial treasure, for its support in Australia, Canada and other sections of the British empire? But while it had been making it had been thus making its way, while it had been coiling itself around the colonial authorities, England had been slumbering [...] but now, behold! As the old gentleman had been showing his foot in England again itself, they were alarmed. ${ }^{18}$ 
Elite and popular reactions to the advance of Catholicism in Britain, such Kay's, never matched the convent-burning episode in 1834 in New England, the Philadelphia Riots of 1844 , or wider "Know Nothing" nativism in the 1850 s. ${ }^{19}$ Yet the continuous intensity of anti-Catholic rhetoric, feeling and action is nevertheless remarkable.

If Britain and the United States were capable of severe forms of anti-Catholicism, Canadian loyalism ensured an even deeper reservoir of vitriol. Taking on a unique character shaped by Tory monarchists like the United Empire Loyalists-exiled supporters of the British against the American Revolution whose arrival shaped religious and political culture among dominant Anglo elites for decades ${ }^{20}$ - Canadian antiCatholicism was additionally laced with both anti-French and anti-Irish feeling. Protestants and Tories felt vindicated in their views when the Rebellion of 1837-38 illustrated the religious and ethnic factors that intertwined with pressures for political reform. ${ }^{21}$ Such pressures, allied to significant Protestant migration from Ulster, ensured Canada would develop the most powerful Orange Order outside Ireland and with it a capacity for violence caused by Old World sectarian cleavages and mirroring the landscape of Ulster, Lancashire and Scotland. Riots in New Brunswick, in 1848 and 1849 , matched anything seen in nineteenth-century Ulster. Equally, Toronto became the "Belfast of Canada" in the 1860s because of its sectarian street battles. ${ }^{22}$

While the broad context was important, priming agents also were needed. Spreading rapidly from its 1790 s Ulster roots, a fiercely militant Protestant society, the Orange Order, would become just such a catalyst. ${ }^{23}$ Its members, many of them Ulster Protestants, became common footsoldiers for some of the preachers. The Order was adept at raising the stakes, countering Catholic gangs, but at the same time encouraging 
reactive, organised Catholic resistance. What we find is working-class Irishmen and Orangemen - Catholics and Protestants - taking sides against each other in the name of their churches and religions, and on behalf of their cleric and political supporters, doubtless encouraged by some of them to adopt the role of physical defenders. In some respects, then, the social history of these lectures, preachers and their effects was an extension of the communal discord of early nineteenth-century Ulster.

Orange-versus-green divisions elicited strong and polarised comment in the press. While, in 1859, Protestant newspapers described events surrounding a De Camin lecture at Wigan as "Romish Intolerance", ${ }^{24}$ the real violence was orchestrated by Orangemen and colliers who took up the cudgels against the baron's Irish Catholic detractors during several days' serious rioting and affray. ${ }^{25}$ In Canada, where the Order was as strong as in Ulster, it was highly involved in general anti-Catholic activity. The Gavazzi riots in Quebec and Montreal, in 1853, as we shall see, were partly the result of militant Orangemen supposedly defending the preacher against his Catholic denigrators. Orangemen were supposed to be protecting one of the most notorious of these figures, William Murphy, in 1871, when 300 Irish miners beat him almost to death in Whitehaven. And Orangemen were among those who, in 1879, became involved in Chiniquy-related violence in Tasmania and who invited Chiniquy to New Zealand. The latter trip was a "major initiative" by the country's Orange Order, the news of which sparked riots prior to his arrival. ${ }^{26}$

\section{The Preachers and Their Motivations}


At the beginning of their careers, the most important motivation for each man was some hitherto existing sense of grievances or misfortune that gave rise to conflict with the church. Critics questioned those preachers with personal narratives of misery, struggle and triumph against all odds. This was certainly true of Andre Masena, the preposterously self-styled Baron de Camin, whose claims were hotly disputed. De Camin was one of the more remarkable manufacturers of self-image. He apparently appeared in England in the early 1850 s as a penniless Catholic who made a living by cleaning boots for Revd Smith of Aylesbury. Later, Dr Waring of Northampton supported him. When Waring withdrew his patronage because De Camin was "a man of very loose morals", he left the Catholic church with dark threats to do all he could to ruin Waring. It was also said to be "quite false" of Masena to claim "that he is a Priest or even a Monk". His marriage was also questioned. "Representations made by this imposter with regard to his wife as having been living in a Nunnery at Winchester", it was asserted, "are altogether void of truth". Like him, she "was originally in household service."27 Other challenges were no less fundamental: during a court case in 1860 a letter from the French Secretary at War was produced which stated the French could find no evidence Baron de Camin was either an ex-officer or a baron. ${ }^{28}$

Some did, however, face struggles in life. Achilli and Gavazzi were hewn from radical nationalism of late 1840 s Italy. Poverty and exile were their reward for being on the losing side in 1848. In Canada, Chiniquy, as a converted French Roman Catholic priest, personified the pressure on French-Canadians to assimilate to Anglo-Saxon Protestant culture ${ }^{29}$. His fame offered insights into the egotistical dimensions of their trade: "in the 1840s Chiniquy was perhaps the best-known Roman Catholic priest in the 
country. In the 1880 s, he was probably the best-known Protestant. ${ }^{\not 30} \mathrm{He}$ cut his teeth, after ordination, as a temperance lecturer and defender of French Catholic causes against the proselytising of "le petit Suisse", French-speaking Protestants who sought conversions in Quebec. Chiniquy's commitment to temperance had earned him the nickname "Father Mathew of Canada". ${ }^{31}$ Chiniquy also engaged in a very specific spat with the Canadian Catholic Church over an emigration scheme designed to encourage Canadian Catholic emigration to Illinois ${ }^{32}$ and the resulting infighting saw him excommunicated. By abandoning his French Catholics roots, he became one of the tres petit Français: the tiny minority of converted French Protestants in Canada. ${ }^{33}$ Perhaps none was so marginal as John Sayers Orr, the Demerara Creole whose driving force was a bitter sense of social inferiority amidst successful white, Portuguese Catholics in his native country. This bitterness transmuted into religious hatred.

Consistently, these men exhorted audiences and authorities to hear their theological arguments. Each lecturer regularly made the claim that they spoke against Catholicism and not against Catholics. They sought to expose the "errors" and "evils" of the "Roman Church"; they did not, it was claimed, intend insult to individuals. In 1878, in the Protestant Hall, Sydney, Chiniquy used the most colourful imagery to make his point: "I do not come here to abuse the Roman Catholics", he stated, "I would prefer to have my tongue cut out and eaten by the dogs, than to speak against Roman Catholics." ${ }^{34}$ Instead, Chiniquy (like Gavazzi) described the "Paganism" or "Heathenism" of the Roman Catholic Church, denouncing idolatry, superstition and sacerdotalism. This led, secondly, to the objective of converting to Protestantism those Catholics who sought true knowledge of the "errors" of Rome. Converts and former priests, such as Chiniquy and 
Gavazzi, could deploy powerful weaponry: first-hand, internal knowledge of what they argued were moral and theological weaknesses in their original faith.

Demands to be taken seriously were lost in the sensationalist language with which their arguments were embroidered. A newspaper editor captured the issue well. He reckoned that if these preachers had been less vitriolic, their words would have been met with polite equanimity. "However", he went on, "the BARON DE CAMIN's lectures do not come under this class. They are violent and offensive invectives ... the Baron must either know he is doing no good, or he must be singularly stupid and wrong-headed. ${ }^{35}$ In truth, the Baron was always like this; and so were others of his creed. Thus, at Manchester, in April 1859, De Camin drew in his audience with threatens to make some "unpalatable disclosures" about Catholicism. As a result, a crowd of Irishmen closed proceedings when they had barely begun. ${ }^{36}$ Similarly, in Hull, in 1860, armed Irishmen prevented him from speaking altogether on the "Holy Doll" ${ }^{37}$ Later, he was allowed to pronounce on how the existence of nunneries in England proved the "Romish Inquisition was in full force here. ${ }^{38}$ Moving on to lecture at the Sailors' Institute, he was recognised as his cab pulled up. Several men pulled him out and, with his hat pulled over his eyes, he was throttled so vigorously that "he grew black in the face, and his tongue protruded". The crowd made to throw him in the docks but were prevented from doing so. After recovering, he was allowed to continue, delivering a short lecture to a much-reduced crowd. ${ }^{39}$ At another meeting, this time in the Midland town of Wolverhampton, he provocatively 'came to the platform, habited in monkish dress'. ${ }^{40}$ Just like Fr Gavazzi, who took to lecturing in a robe embroidered with an open bible ${ }^{41}$-a reflection of the belief that Protestants read the scriptures themselves while attacking Catholicism, 
wherein priests mediated the holy book for flocks characterised as subservient and undiscerning. Each of these elements was, moreover, sculpted to create intense effect in the mostly hostile audiences.

Thus, sensationalism, provocation and spleen were not random attributes. Taking on the hostile crowd swelled the ranks of the interested many times over. A scholarly lecture for a polite middle-class crowd would not sell tracts by the thousand nor fill halls every night of the year, and these lecturers clearly realised it. Moreover, as their infamy grew so did the crowds paying money to see them. The "good crowds" packed into churches and halls seem to have ranged from 50 or 60 to 200 or so. In June 1853,800 packed the Free Presbyterian Church, St Genevieve St, Quebec, for one of Gavazzi's lectures. $^{42}$ Gavazzi charged a fairly standard entrance fee of $2 \mathrm{~d}$ to 1 s entrance to his lectures in Britain and hundreds attended most of them. The "receipts were sufficient to make him a living, with enough left over to support penurious Italian exiles in Soho."43 Chiniquy was particularly interested in money and was criticised for it. He travelled in comfort on the back of his lecturing and good crowds were charged according to the class of the clientele. For Chiniquy, though, it was the sheer frequency of his lectures that earned the money. In 1860, he packed the Free Assembly Hall, Edinburgh, at 3d a ticket, ${ }^{44}$ but then, on the same trip, asked from a penny to $3 \mathrm{~d}$ for a ticket to his lecture at the Portobello Free Church. ${ }^{45}$ The New Zealand press reported Chiniquy's ambiguity over money: "[he] vows he never kept a cent for himself", though claims "I am pretty well off myself without being rich." ${ }^{46}$ His wealth was constructed on a magnificent award of $£ 500$ from the Canadian parliament in recognition of his temperance crusade. ${ }^{47}$ In the late 1870 s, he accrued $£ 4,600$ in Australia but claimed $£ 3,700$ went on expenses. In New 
Zealand he garnered $£ 1609$ with over $£ 1000$ spent on expenses, including books and pamphlets, living costs and a $£ 42$ for comfortable passages to San Francisco for him and his entourage. ${ }^{48}$ When Chiniquy uttered a profane blessing and destroyed some holy wafers, the Tory press responded by questioning the money he made. '[T]he 'Pastor' has managed to reap a rich harvest in England; however, as usual he needs "just a few more pounds" to enable him "to save a few more Ritualists and Romanists." ${ }^{, 49}$ Indeed, he was still implying the need for money for his work of conversion: "more than a 100 of my Roman Catholic countrymen [in Canada] have broken the ignominious and heavy yoke of Popery these last few months", he told readers of the Friendly Companion in a letter, but "the number would be much greater if we had the means to support more labours in the field". 50

A variety of factors, then, made these men popular. Their exoticism clearly aided their popularity. Organizations such as the Orange Order promoted their lectures and sold the pamphlet literature that distilled the same types of viewpoints. There is no evidence that Protestant clerics discouraged their flocks from attending their lectures. In isolation, these factors were not enough. Collectively, when underscored by the written and spoken word, the impetus became stronger. One newspaper captured the combination of prurience, potential insight and mischief that drew together diverse, divided and differentiated audiences for the likes of Andre Massena, the Baron de Camin: 'the circumstances of his having — after being a Roman Catholic priest for some 20 yearsseceded from the Catholic communion, no doubt led a large number of Catholics to attend, some perhaps with the view of hearing him, but a large number, it would seem, for the purpose of silencing him. ${ }^{51}$ Quite deliberately, however, these men did not take a 
scholarly approach to the articles of the Catholic faith. There is certainly no evidence that they were publicly involved in making speeches that dealt in detail with the types of theological and medical debates about the physical effects of celibacy and Catholicism that Verhoeven's article explores. ${ }^{52}$

Allusions to the "Holy Doll" and phrases such as "the Confessional Unmasked" deliberately provoked the baldest types of Protestant prejudice. De Camin was not alone in lecturing on that old classic, 'the inquisition'. ${ }^{53} \mathrm{He}$ also was advertised to speak at the Athenaeum in Carlisle, in 1855, on "Nuns and Nunneries", with the "sole of objective" of the lecture being to make a petition to the parliament to inspect convents - a controversial topic with Catholics and church authorities. ${ }^{54}$ The chapter titles of Chiniquy's The Priest, the Woman and the Confession, capture the extraordinarily provocative nature of their written and spoken words. "Auricular Confession a deep Pit of Perdition for the Priest" and "the Confession is the Modern Sodom" offer two telling examples. Meanwhile, Gavazzi spoke and published on "Romanism and Paganism”, "the Romish system”, "the Inquisition", "Jesuits", and "the Infallibility of the Pope". Each of these topics was calculate to challenge Catholics in the most direct and stentorian way. The strongest theme was, however, claims of sexual deviance of Catholics and Catholic priests and monks, underpinned, they claimed, by the challenges of celibacy. ${ }^{55}$ This crucial gender aspect is considered now.

\section{Gender and Sexuality}


Protestant views of Catholicism were partly shaped by abhorrence at what were viewed as questionable gender practices: the cloistering of nuns in communes divorced from society, and the issue of celibacy, with priests and monks portrayed as wrestling with this impossible, unnatural vow. The separation of male and female, and the abstinence from sexual practices, tapped into deeply held Victorian views about the role and place of women. Indeed contemporary anti-Catholic rhetoric and some medical thought suggested celibacy was described as physically and psychological as well as morally dangerous. ${ }^{56}$ There can be little doubt that the gender content of these preachers' lectures-with their favoured emphasis on the confessional as a topic - helped to pull in audiences wherever in the world they went.

It is somewhat ironic, then, that some of the most common peddlers of slights upon the Catholic vow of celibacy and the resulted alleged sexual malpractice should be themselves sexual deviants, frauds and transgressors of such vows. Certainly, few of the men in question could hold themselves to the same high standards they demanded of a reformed Catholic church. One of them, former Dominican priest called Giacinto Achilli appeared to personify the Protestant idea of the licentious priest. A serial seducer of low morals, he courted controversy and consternation wherever he went. At least four women were the victims of his seduction - two of them the wives of men who befriended him. He also was accused of raping or molesting five other women and girls. After being drummed out of the priesthood, he went to Britain via Corfu. In 1853, after winning a spectacular libel case against John Henry Newman, who had questioned his description of his past, Achilli emigrated to the United States in the company of a Swedenborgian sect and worked sometimes for the US Protestant Missionary Society. In 1859 he was 
arrested for adultery and fornication with his son's governess who became pregnant with his child. Achilli's defence was that the woman was really his wife. ${ }^{57}$

While Chiniquy undoubtedly lacked Achilli's serial immorality, he too left the church as a failed priest of suspect morals. Detractors like the British Jesuit Sydney Smith sought to counter the pastor's influence in Britain by publicly doubting his moral standing. ${ }^{58}$ Additional evidence against him in this respect included affidavits from women he allegedly seduced. When Chiniquy married, in 1864, some of the newspapers sneered how, by marrying, he had following "the example of Luther": "unlike Luther, however, he has not found a nun to share his joys and sorrows". 59

De Camin also was called upon to defend his reputation against defamation and character assassination. Mistreatment of women was again a charge. When his "wife" claimed he had abandoned her and three children without money or food, De Camin went to court to assert that they had been joined in an "illegal marriage". He nevertheless supported her. He also showed another of his character traits when, not for the first time, he lost his temper with courtroom officials. ${ }^{60}$ Such charges of neglect were not new to De Camin: there had been a previous case when it was claimed Manchester poor law guardians were caring for a woman who was his wife. On this occasion he made arrangements to repay the costs. ${ }^{61}$

The commonest victim of their ire was what Chiniquy called the "diabolical and filthy auricular confession": once again, the issue of gender was the key. Without an antidote to such Jesuitical practices, as he saw them, Chiniquy declared, "[t]he Episcopal Church is doomed to perish in that dark and stinking pool of Popery". ${ }^{62}$ In their attacks on the confessional, these preachers embodied what Richard Hofstadter memorably 
dubbed "the pornography of the puritan". ${ }^{63}$ Heavily gendered, placing women in the position of pathetic victims, they offered the most lurid tales of sexual usury in convents and priestly prying in the confessional. At the heart of the matter, was the Catholic woman, alone and at risk in a small booth with a lascivious cleric, who, despite his vow of celibacy, was a suitor of the most apparently twisted kind. Presumably Chiniquy's own struggles with the vow of celibacy had some effect on his assessment of the evils of the system: he certainly described the effects of celibacy in the case of a monk who castrated himself to diminish sexual feelings and passions. ${ }^{64}$

Chiniquy brought together pagan and Catholic rituals in an extraordinary attack:

There are two women who ought to be constant objects of the compassion of the disciples of Christ ... the Brahmin woman, who, deceived by her priests [and] burns herself on the corpse of her husband to appease the wrath of her wooden gods; and the Roman Catholic woman, who, not less deceived by her priests, suffers a torture far more cruel and ignominious in the confessional-box, to appease the wrath of her wafer-god. ${ }^{65}$

One tactic to get around the near-pornographic content of their lectures on the confessional was to restrict them either to men or men and Catholic women (on the grounds the latter had already experienced the evils of the practice anyway). Others ignored the potential sensibilities and incensed middle-class opinion. De Camin was criticised in Belfast when his utterances at the Victoria Hall were considered "wholly 
unfit for a mixed audience", thus producing "flushed cheeks amongst the few ladies who attended." 66

Naturally enough, the priest was the principal target of attacks on alleged sexual practises within Catholicism. Sacerdotalism ("priestcraft" as it was sometimes dubbed in an open association with witchcraft) drew much attention; the confessional and the celibacy of priests were woven together in a generally mystical portrayal of prurience and salaciousness. Particular focus was placed on the sacerdotal vow of celibacy. Gavazzi argued that because the papacy imposed celibacy upon priests, it renounced "the law imposed by God on all His creatures". ${ }^{67}$ While critics searched for sexual misdemeanour in all these men, Hall claims "no opponent could bring any calumny against" Gavazzi on this issue. ${ }^{68}$ Chiniquy, whose written words on Catholic ritual and laws were as dark as any, wrote of the vow of celibacy as if he had been its victim-which, of course, he had. The vow, he reckoned, was the product of

Ingenious tricks, pious lies, shameful stories called miracles, and sacrilegious perversions of the Word of God made use of by superiors and seminaries and nunneries to entice their poor victims into the trap of perpetual celibacy.

Chiniquy mocked the idea that because of their chastity nuns and priests benefited from "miracles wrought by Christ. He lambasted the passages of Matthew 12:13 ('and there are eunuchs which have made themselves eunuchs for the kingdom of heaven's sake') which is used 'by the superiors to persuade the young people ... to bind themselves by those shameful vows." Chiniquy used the words of the Bible to argue that there was no 
evidence that "the Saviour [who] speaks of a state of celibacy" suggested it had "to begin on this side of the grave". He also used his own experiences of debate within seminary, the battle with his intelligence and conscience, and his final, anguished decision in 1832 to accept the vow himself. These words from his own autobiography appear as an excuse for his breaking of the vow. ${ }^{69}$

\section{Violence, Disorder and Irish Catholic Immigrants}

No-popery preaching divided communities. Catholics and liberal commentators viewed the men as provocative and profane, their lectures as an outrage against faith, reason and common humanity. In response, Protestants and the Tory press invoked freedom of speech to demand the right to hear them. The authorities juggled resistance to mob rule with a defence of individual liberty. Working-class Irish Catholics, who were hard-wired to defend the church and its officers, had one consistent objective: to stop, and sometimes to harm, the speakers. Lecturers of this type thus ran the risk of serious injury. Baron de Camin was regularly pushed, pulled and worsted by angry crowds. William MurphyVictorian Britain's most notorious no-popery demagogue - was beaten so viciously in 1871 by Irish miners in west Cumberland that he never fully recovered and died a year later. ${ }^{70}$ The maudlin Pastor Chiniquy regularly spoke of his death, as though it were a risk he ran. In New Zealand in 1880 he dismissed such fears because "was seventy years of age and a year or two more or less of life would matter little to him as he not die in a better cause." ${ }^{71}$ A few weeks later he told another audience in the country "to pray for him —he was with them tonight; in a week he, perhaps would be in his grave-who could tell[?]" ${ }^{72}$ John Kensit, who established the Protestant Truth Society (1889) and set up the 
Wickliffe Preachers to crusade against Ritualism in the Church of England at the turn of the century, was killed at Birkenhead, in 1902, by an Irish Catholic's two-pound iron file. In 1892, the American Protective Society and Anti-Catholic Society speaker, Thomas F. Lyons answered turbulent critics by wounding two and killing one with his sixshooters. $^{73}$

While these preachers could be savagely attacked, serious affray among rival crowds was more common. In an early example, in 1851, with the "Papal Aggression" controversy raging, John Sayers Orr, the soi-disant "Archangel Gabriel”, caused chaos in the Clydeside town of Greenock with harangues against the pope's "aggression" in reestablishing Catholic church governance to cope with huge influxes of Irish coreligionists. Dismissed as "an illiterate half-wit", he was in fact an audacious, gifted orator who was capable of serial rabble-rousing. ${ }^{74}$ His wit and wherewithal enabled him to fulfil speaking engagements across Britain and North America, whipping up violence in New York, Montreal, Greenock, Glasgow, and his native Demerara with his "harangues against Roman Catholics, whom he accused of all kinds of crimes and immoralities." 75 After two days of riot, Greenock's Catholic chapel and the priest's house had been badly damaged and Irish workers' homes ransacked, and, in a fit of panic, the local authorities laid off the Irish employed on public works. The mob, numbering over 600 , then went to nearby Inverkip to attack the Irish workers there. The "Archangel Gabriel" slunk away until he made the news in Boston, in May 1854, where crowds followed him from place to place, clashing with Irish labourers and attacking Catholic property. At New York and Brooklyn, large and restive crowds were held at bay by "a whole army of special police", but there were still clashes. ${ }^{76}$ During this period, Orr was 
to be found ranting to crowds of up to 10,000 in New York. ${ }^{77}$ He eventually returned to Demerara where, in 1856, he was arrested, tried and sentenced to hard labour for unlawful assembly, libel, and incitement to violence against successful, middle-class, Portuguese Catholic traders. ${ }^{78}$ Orr was in the habit of using "the most disgraceful language towards the nuns" and "publicly insulted" the Catholic bishop. ${ }^{79}$ Whilst he was confined, Orr contracted dysentery and died aged $35 .{ }^{80}$

Slanders against the officers of Catholicism evoked fierce reprisals from Irish Catholics who revered their priests. Alessandro Gavazzi has been described in some circles as a sincere and intellectual Mazzinian nationalist who did not convert to Protestantism: a reasoned, not rabid, critic of Rome ${ }^{81}$ Yet his lectures elicited just as much violence as those of his more lumpen peers. Thus it was on 6 June 1853 when Gavazzi's lecture on the Ribbon sympathies of Irish priests during a speech at the Free Presbyterian Church, Quebec drew fierce, physical counter-blows. ${ }^{82}$ When the lecturer was saying "the Romish inquisition extended to Ireland through the agency of Ribbonism"- an anti-Protestant, anti-Orange Irish secret society emerging from the 1798 Defenders tradition - the mob outside was alerted and proceeded to break into the church armed with stones and clubs. An advanced guard made for Gavazzi on the stage, and something redolent of a saloon brawl, he fought off several assailants with a chair. Eventually overpowered, the lecturer was dragged away by his legs before his entourage rescued him and the military cleared the church. As the press reported, "Gavazzi's secretary was "dreadfully injured," with several blows to the head, but had recovered the next day. ${ }^{83}$ It was claimed that some in the audience had sneaked muskets into the church where Gavazzi was speaking and the liberal use of guns led the military to be mustered. 
During the initial exchanges of fire one person was killed and another wounded. ${ }^{84}$ By the time third despatches came out from Montreal, the death toll had climbed to seven, with 11 wounded. ${ }^{85}$ The London press also added another ingredient to the brew: the incendiary presence of Orangemen shipped into Quebec from Toronto. ${ }^{86}$ Tory Protestant newspapers, such as the British Banner made no apology for the Orangemen's role. Indeed, they saw it as no more than necessary in a city such as Montreal, where the "Romish Mayor" was accused of favouritism and the where the Solicitor General also was "a Catholic". ${ }^{87}$ The New York press developed this theme: not only had the Orangemen turned up in anticipation of violence, but they had also escorted Gavazzi to his lodgings, remarking that the scenes at Quebec were created by a combination of Gavazzi's incendiary suggestion of a sacerdotal connection to Ribbonism, the presence of the Orangemen (many of whom would have been Irish Protestants), and the general willingness of Irish Catholics to use violence to address their grievances. The Quebecois were exculpated of any sins. ${ }^{88}$

Against all logic, but in accordance with a libertarian and pro-Protestant ethos that tolerated such lectures in the first place, Gavazzi was allowed to repeat his lecture at the Zion Church in Montreal. Once again the authorities lost control of the situation. Respectable families apparently gathered to hear this lecture; as was common, the rougher sorts milled about outside. What was described as "a band of Irish Catholics" then charged the church and several were shot in the resulting clash with the police and a detachment of the Cameronian Highlanders. Just as matters calmed, a peaceable crowd was fired on as it headed home, with numerous wounded and several more killed. ${ }^{89}$ Among the dead and severely wounded were a prominent builder called Hutchison, two 
clerks, a bookseller, a city councillor's son called Adams, and a five-year-old boy. Whilst the opponents of Gavazzi were usually Irish or French, the names of those wounded and killed suggest an Anglo-Saxon or Scottish group of supporters or passers-by, some of them prominent in society. ${ }^{90}$ It seems highly unlikely they were perpetrators of the riot. For Gavazzi's part, he wrote to the Italian press (with translations appearing in the US papers) with a tone of relief and vainglory. As he headed for New York leaving animosity and bitterness behind, he thanked God because he had "escaped the death of my assassins". ${ }^{91}$ No comment was offered on the many people who lay dead and injured as a result of his invective.

Some in the American press denounced the denial of Gavazzi's freedom of speech and, somewhat dubiously, compared the Canadian scenes unfavourably with apparently more enlightened goings on in New York and Boston, where "men of every shade of opinion continue to hold forth $\ldots$ and their right to speak is never questioned. ${ }^{.92}$ In October, the mayor of Montreal, Charles Wilson, was arrested for murder, along with numerous rioters whose names suggested a blend of Irish and French Catholics. ${ }^{93}$ By November, the incident had been reported as widely as the Australasian colonies. ${ }^{94}$ There was also a kind of knock-on effect. New York's Weekly Herald described attacks by German Protestants in Cincinnati on Gaetano Bedini, the Pope's nuncio, as similar in character and cause to the Gavazzi riots in Montreal. Bedini visited the United States from his posting in Brazil in June 1853. Instructed to observe Catholicism in the US and to talk to the president and the bishops, his trip was a source of controversy from the beginning, and one seized upon by the "Know Nothings". ${ }^{95}$ Moreover, Gavazzi sought some advantage in the controversy over Bedini by charging that he had done nothing to 
save Italian patriots of the 1848-9 revolution from being executed. Indeed Gavazzi considerably increased the tension levels by claiming the nuncio was none other than the "bloody butcher" who killed Ugo Bassi, the "favourite chaplain of Garibaldi". Gruesome details unfolded of how Bassi's skin was peeled from his forehead and hands before "he [was] flayed alive". ${ }^{96}$ The resulting riots and social discord pointed to intolerance on both Catholic and Protestant sides, the press reckoned, as well as general turbulence within foreign-born populations: German liberals against Bedini, Irish Catholics defending their co-religionist. The episode was certainly grist to the mill of anti-immigrant feeling manifest in the growing Now-Nothing movement. ${ }^{97}$

Such mobs seemed to be everywhere. As debates over Montreal and its effects raged on in North America, Gavazzi returned to England where he was soon being "maltreated" by an Irish mob in Preston. ${ }^{98}$ In Birmingham, in 1858, where later William Murphy would make his home, Irish Catholics shouted him down as he laid into priests as guilty of adultery, murder and "yet fouler crimes". ${ }^{99}$ In Walsall, the local priest had to intervene when a large crowd, tired of his lectures on "popery", surrounded the Guildhall to prevent him speaking. ${ }^{100}$ In the same year, in Wolverhampton, the keeper of the Exchange received a warning letter claiming a "pretty lot of Irishmen" were plotting to attack De Camin's lecture. ${ }^{101}$ A huge crowd of 3,000 Irishmen armed with sticks, pokers and stones duly stopped proceedings. While magistrates resolved to protect his right to speak, De Camin considerably increased the temperature prior to the next outing, laying down a gauntlet to those whose liberties he thought imperilled: 
If an Irish rabble and Popish adherents; who are only the tools of the Popish priesthood and Jesuits, and their dupes, can only stop the circulation of the truth by riots, and threatening to destroy lives and property, then your glorious liberty is in danger. Men and women of Wolverhampton, sons and daughters of Great Britain, as Protestants I appeal to you as Paul did to Caesar, to protect me and give me fair play and a fair hearing $[\ldots]$

De Camin ascended the stage dressed as a monk with various symbols and icons of Catholicism about him and the crowd, both inside and out, heckled and whistled. Matters descended into a free-for-all and the riot act was read. Only two arrests were made: mere tokens of a long night of rioting, window-breaking, and fighting with police. ${ }^{102}$

The climactic year of 1862 saw the baron involved in a series of riots in both Ireland and Britain. While Irish Catholics revered and defended the papal office against general denunciation, they also had a particular cause to fear Garibaldi's march on Rome. Gavazzi and De Camin denounced Irish Catholic subservience and portrayed Garibaldi's march as a crusade against the papacy. ${ }^{103}$ Thus the general tenor of sectarian feeling was heightened by a clash of religious authority and secular nationalism. De Camin's reception in Enniskillen in January of 1862 saw local Catholics barring the town hall to prevent his first lecture. Then "supplied with whisky" and "furnished with tickets", 50 to 100 of "the lowest scoundrels" tried to disrupt proceedings from within. Despite the presence of weapons on both sides, the Protestants, who were more numerous, cleared the Catholics from the hall. ${ }^{104}$ In the same year, Chesterfield was convulsed by the most remarkable riots in its history during the Baron's several days' lecturing there. To stop 
him speaking, up to 2,000 Irish gathered with pokers, shillelaghs and "life preservers" (a weighted ball on a stick). They succeeded in scaring him off. ${ }^{105}$ At Wakefield, in August, Irish Catholics mobbed the theatre and prevented him speaking and Protestant gangs attacked the Irish areas. ${ }^{106}$ In Bradford, the Baron was pulled from the wherry from which he was giving an open-air lecture and lost his hat and cloak at the hands of a yelling, stone-throwing Irish mob. ${ }^{107}$ In December, after he had left following his second visit, the Irish population in a state of agitation, an innocent man named Cooper walking his sweetheart home was struck a mortal blow from an Irishman's "life-preserver". ${ }^{108}$

De Camin's sojourning also took him to North America, where violent disapproval was also forthcoming against his "fanatical" lectures. Once again, the importance of the local state was clear. In 1872, at Ogdensburg, New York State, Irish Catholics riots mobbed the hall where he was speaking and the mayor and police sought to protect his freedom to speak. To do so, the weight of the state fell firmly down against Irish Catholic crowds, with a large number of special constables sworn in. ${ }^{109}$ Moreover, the mayor issued a public proclamation in favour of De Camin's right to address his audiences in the town. ${ }^{110}$

For the apostate French-Canadian Charles Chiniquy, Quebecois hostility was an ever-present threat on home soil. At Montreal in 1875, one of his sermon FrenchCanadians "of the baser sort" interrupted him by singing a "shantyman's boating song, entitled 'En Roulent Ma Boule". ${ }^{111}$ Again in 1884, there was more intense rioting in the city following further lectures by Chiniquy. This time matters were worsened a riotous mob put out the lights and windows of the hall in which he was due to speak. ${ }^{112}$ Local 
memories of the Gavazzi riots, during which police shot many Catholics, were said to spur these new hostilities. ${ }^{113}$

From 1878 to 1880 it was the Irish of Australia and Tasmania who rioted against him. ${ }^{114}$ Once again, freedom of speech clashed with freedom from insult. There was a notable middle-class element here, too. Hobart Catholics were indignant that the author of "grossly immoral publications" should be allowed to use a town hall, a facility maintained with Catholic ratepayers' taxes. On Tuesday 24 June 1878 fighting erupted at Chiniquy's lecture, shocking the respectable elements of the audience, including women who rushed towards the stage to escape a "stout and elderly Irishman" and his coreligionists who cried "Tally ho! Tally ho!" Chiniquy hid by the organ. Appeals were made for the pastor to be heard; English "fair play" was invoked and a calming hymn was suggested. Instead a bantering version of "God Save the Queen" sounded out; his opponents would not leave and "three groans for the apostate priest" was their exhortation. Once order was restored, the post mortem lamented the loss of freedom of speech (as all such post-mortems did) and the police came under fire. The authorities sought ways for Chiniquy to be heard. But a massed crowd of 4,000 or more, packed inside the Town Hall, was met with a concerted Irish Catholic break-in. The police were brushed aside, an impasse was achieved, and despite appeals and negotiations, Chiniquy did not appear, and the Irish declared a victory. ${ }^{115}$

The tumult in Tasmania alerted the New Zealand Orange Order, which invited him across the Tasman Sea. News of Chiniquy's imminent arrival led to New Zealand's fiercest sectarian rioting between Orangemen and Hibernians, immortalised in Thomas Bracken's satirical folk verse, “The Saige o' Timaru”. The absence of violence once 
Chiniquy had arrived was, however, down to several factors: the calculated indifference of "lace curtain" Irish folk; demands for peace from the church; punitive policing of earlier riots; Chiniquy's avoidance of New Zealand's West Coast; and a general absence of sectarianism in New Zealand. These elements combined to ensure Chiniquy's trip to the farthest shore bore none of the hallmarks of Tasmania and Montreal. Chiniquy himself also adopted a modest tack, dropping controversial topics, such as the unmasking of the confessional. The press allowed for a little self-promotion, applauding the tolerance, fair play, and quietude of the New Zealanders. ${ }^{116}$

Violence and intimidation had the counter-productive effect of confirming the perceived savagery of the working-class Irish Catholic crowd. Since liberty and freedom of speech were the enduring principles which saw so many local administrations tolerating the obvious risks of having preachers in their midst, Catholic opposition to the preachers suggested, to some at least, that Roman church was hostile to liberty and intellectual inquiry more generally. The extent to which violence by ordinary Irish Catholics was an official one sponsored by their church hierarchy, is impossible to prove, it is reasonable to assume the Catholic Church was hostile to such terrible denunciations of their credo and expected their flocks to defend the church's honour. In this regard, the application of violence to thwart or limit the lecturers' exposure was actually very successful.

\section{Conclusions}

Amidst the drama of the baying mob, lecturers such as these took great risks and caused significant damage: not just to property and persons but also to the psychology of 
communities. Local studies suggest a long-living sense of perceived slight, victories won and losses suffered. A need for revenge sometimes was evinced once the lecturers had gone. In return, the speakers took considerable personal risks. None went entirely unmolested and Murphy and Kensit were killed. On the other hand, rewards were considerable. It is hard to imagine anyone taking notice of characters as ludicrous as Baron de Camin and John Sayers Orr if they had not spiced their offerings with invective. Possibly a quiet, scholarly approach would have led Pastor Chiniquy to Scotland, where regardless of the controversy surrounding him, his evangelical Presbyterianism was treated seriously. ${ }^{117}$ On the other hand, without lurid tales of the confessional and gaspinducing passages on Rome's risk to women, it is doubtful if the Orangemen in Hobart or Auckland would have paid his fare.

These preachers are best seen as popular entertainers who tapped ancient British prejudices-prejudices that eventually spanned the globe as a measure of transnational cultural attachments which were rather less lofty and rather more disagreeable than other things Britons and neo-Britons held dear. Their speeches contained no great theological arguments; their words offered salacious, prurient and threatening entertainment. Yet, the success of these itinerant lecturers suggests that both the US and Canada had yet to break free of the Old World in terms of anti-Catholicism, with even Australia and New Zealand on occasion falling foul of the contagion of religious discord. At the dawn of the Edwardian era, commentators in places like New Zealand still could mark news of a tour by America's noted controversialist, Joseph Slattery, as a "crusade of filth plus shekelseeking". ${ }^{118}$ By then, however, this type of entertainment was a dying public spectacle: it 
reached an apogee in the Victorian age and ceased to be a mass spectacle by the First World War.

${ }^{1}$ Linda Colley, Britons: Forging the Nation, 1707-1837 (London: Yale University Press, 1992).

${ }^{2}$ In Australia, the Church Act (1836) enshrined the equality of the four largest denominations. Hilary M. Carey, "Religion and Society", in D.M. Schreuder and S. Ward (eds), Australia's Empire (Oxford: Oxford University Press, 2008), 189.

${ }^{3}$ W. Ralls, "The Papal Aggression of 1850: a Study in Victorian Anti-Catholicism”, in Gerald Parsons (ed.), Religion in Victorian Britain Vol. 4, Interpretations (Manchester: Manchester University Press, 1988), 115-34.

${ }^{4}$ John Wolffe, The Protestant Crusade in Great Britain, 1829-1860 (Oxford: Oxford University Press, 1991) is the key work on broad-based British anti-Catholic mobilization; D.G. Paz, Popular Anti-Catholicism in Mid-Victorian England (Stanford, CA: Stanford University Press, 1992), is a major study of the popular dimensions.

${ }^{5}$ Migrations of people and ideas are recognized in a recent important study of the sinews of the British World: Magee and Thompson, Empire and Globalisation: Networks of People, Goods and Capital in the British World, c.1850-1914 (Cambridge: Cambridge University Press, 2010).

${ }^{6}$ Paz, Anti-Catholicism, 24-25 notes the mix of danger and entertainment in the Victorian lecturing tradition. Also, see Donald M. Scott, "The Profession that Vanished: Public 
Lecturing in Mid-Nineteenth Century America", in G.L. Geison (ed.), Professions and Professional Ideologies in America (Chapel Hill, NC: North Carolina University Press, 1983), 12-28.

${ }^{7}$ John Wolffe, "A transatlantic perspective: Protestantism and national identities in midnineteenth-century Britain and the United States”, in Tony Claydon and Ian McBride (eds), Protestantism and National Identity: Britain and Ireland, c.1650-1850

(Cambridge: Cambridge University Press, 1998), 291-309 and his "Anti-Catholicism and the British Empire", in Hilary Carey (ed.), Empires of Religion (Basingstoke: Palgrave Macmillan, 2008), 43-63.

${ }^{8}$ Peter Cherches, "Star Course: Popular lectures and the marketing of celebrity in Nineteenth century America." (PhD Thesis, New York University, 1997); Donald M. Stott, "The Popular Lecture and the Creation of a Public in Mid-Nineteenth-Century America", Journal of American History 66 (March 1980): 791-809 and his "profession that vanished", 12-28.

${ }^{9}$ Paz, Popular Anti-Catholicism, 2, notes Pastor Chiniquy's sojourns but does not pursue them.

${ }^{10}$ W.L. Arnstein, “'The Murphy Riots': A Victorian Dilemma”, Victorian Studies, 19 (1975-76), 51-71, captured this balancing act well.

${ }^{11}$ Enda Delaney, 'Our island story? Towards a transnational history of late modern Ireland', Irish Historical Studies, 37, 148 (November 2011), 83-105.

12 "Pastorini”" was Catholic prelate, Charles Walmsley.

${ }^{13}$ Correspondence, 14 March 1821, Sirr Papers, 869/3, Trinity College Dublin; J. S. Donnelly Jr, Captain Rock: The Irish Agrarian Rebellion of 1821-24 (Cork: Cork 
University Press, 2009), passim. As examples of Protestant hysteria, see The Age, 21 July 1839, 19 January 1840; John Bull, 16 August 1840.

${ }^{14}$ Mormon missionaries for example made landfall in Liverpool in 1837. R.J. Evans, $A$ Century of Mormonism in Great Britain ... (Salt Lake City UT, Deseret news press, 1937). R. Carwardine, Transatlantic Revivalism: Popular Evangelicalism in Britain and America, 1795-1865 (Westport, Conn: Greenwood Press, 1978).

${ }^{15}$ Wolffe, chs 1-3; Colley, 324-34.

${ }^{16}$ R.A. Billington, The Protestant Crusade, 1800-1860 (1938; Chicago: Quadrangle Press, 1952 edn), ch 3.

${ }^{17}$ G. Parsons, "Victorian Roman Catholicism: Emancipation, Expansion and Achievement", in Gerald Parsons (ed.), Religion in Victorian Britain, 4 vols (Manchester, 1988), I: Traditions, 146-83; W. R. Ralls, “The Papal Aggression of 1850: a study in Victorian anti-Catholicism" in G. Parsons (ed.), Religion in Victorian Britain, IV: Interpretations, 115-34.

${ }^{18}$ Preston Chronicle, 7 Dec 1850, 6. 
${ }^{19}$ The Charlestown Convent: Its Destruction by a Mob, on the Night of August 11, 1834 ... Also, the Trials of the Rioters, the Testimony \& the Speeches of Counsel (Boston: Donohoe, 1870); Michael Feldberg, The Philadelphia Riots of 1844: A Study of Ethnic Conflict (Westport, Conn.: Greenwood Press, 1975); Tyler Anbinder, Nativism and Slavery: The Northern Know Nothings and the Politics of the 1850s (New York and Oxford: Oxford University Press, 1992).

${ }^{20}$ The historiography of loyalism is huge, but see Maya Jasanoff, Liberty's Exiles: The Loss of America and the Remaking of the British Empire (London: Harper Press, 2011), and the sources cited there.

${ }^{21}$ Allan Greer, “1837-38: Rebellion Reconsidered”, Canadian Historical Review 76, 1 (1995): 2-18.

${ }^{22}$ S.W. See, Riots in New Brunswick: Orange nativism and social violence in the 1840s (Toronto: Toronto University Press, 1993) and C.J. Houston and W.J. Smyth, The Sash Canada Wore: An historical geography of the Orange Order in Canada (Toronto: 1980).

${ }^{23}$ Donald M. MacRaild, "Wherever Orange is Worn: Orangeism and Irish Migration in the $19^{\text {th }}$ and early $20^{\text {th }}$ centuries", Canadian Journal of Irish Studies 28/29, $2 / 1$ (2002/3): 98-117.

${ }^{24}$ Belfast News-letter, 2 July 1859, p.4.

${ }^{25}$ Preston Chronicle, 2 July 1859, pp 4-5; Morning Chronicle, 4 July 1859, p.4.

${ }^{26}$ S. O'Brosnahan, "The "Battle of the Borough" and the 'Saige of Timaru': Sectarian Riot in Colonial Canterbury”, New Zealand Journal of History 28, 1 (2004): 51.

${ }^{27}$ Ipswich Journal, 7 November 1863, p.8.

${ }^{28}$ Morning Chronicle, 29 July 1852, pp 7-8; Hull Packet, 27 January 1860, p.6. 
${ }^{29}$ This is the argument of Paul Laverdure, "Creating an Anti-Catholic Crusader", Journal of Religious History 15, 1 (June 1988): 94, 96-7.

${ }^{30}$ From the Canadian, 11 September 1976, quoted in Paul Laverdure, "Charles Chiniquy: The Making of an Anti-Catholic Crusader", CCHA, Historical Studies, 54 (1987): 39.

${ }^{31}$ Laverdure, 47.

${ }^{32}$ Chiniquy, Fifty Years, 511.

${ }^{33}$ Curreen, p.11; S.L. Warne, "Sectarianism in Hobart: The Chiniquy disturbances, 1879”, Unpublished BA (hons) Thesis, University of Tasmania, 1977, 33.

${ }^{34}$ The Chiniquy Lectures, As Delivered in the Protestant Hall, Castlereagh Street, Sydney (Sydney, 1878), 13.

${ }^{35}$ Leeds Mercury, 17 September 1862, p.2.

${ }^{36}$ The Standard, 5 April 1859, p.7.

${ }^{37}$ Manchester Times, 14 January 1860, p.6.

${ }^{38}$ Hull Packet, 20 January 1860, p.6.

${ }^{39}$ Hull Packet and East Riding Times, 13 January 1860, p.5; Birmingham Post, 5 April 1859, p.1, 12 January 1860, p.3, 13 January 1860, p.3.

${ }^{40}$ Leeds Mercury, 5 April 1859, p.2; Hull Packet and East Riding Times, 2 July 1858, p.7.

${ }^{41}$ Church and State Gazette, 17 November 1854, p.722.

${ }^{42}$ New York Times, 10 June 1853, p.1.

${ }^{43}$ Paz, Anti-Catholicism, 25.

${ }^{44}$ Scotsman, 3 October 1860, p.2.

${ }^{45}$ Scotsman, 4 October 1860, p.1. 
${ }^{46}$ [Auckland] Weekly News, 27 March 1880.

${ }^{47}$ E.M. Dollery, “The Chiniquy riots, Hobart", Tasmanian Historical Association, Papers and Proceeedings, vol.8, no.1 (August, 1959), 120.

${ }^{48}$ Curreen, "Pastor Charles Chiniquy", 45-7 for the monies raised in Australia and New Zealand.

${ }^{49}$ John Bull, 23 June 1883, p.39; also 26 May 1883, p.329; 23; 2 June 1883, p.34; 9 June 1883 , p.36.

${ }^{50}$ Friendly Companion, 1 November 1888, p.34.

${ }^{51}$ The Standard, 5 April 1859, p.7.

${ }^{52}$ Timothy Verhoeven, 'Harmful or benign? Doctors, celibacy and transnational antiCatholicism, Journal of Religious History ...

${ }^{53}$ Manchester Times, 16 July 1859, p.6.

${ }^{54}$ Carlisle Patriot, 17 February 1855, p.4.

${ }^{55}$ Charles Chiniquy, The Priest, the Woman, and the Confessional (London, Marshall

Press, n.d.); Father Gavazzi's Life and Lectures (New York: De Witt and Davenport, 1858).

${ }^{56}$ Verhoeven, "Harmful or benign?"

${ }^{57}$ For a succinct telling of Achilli's bizarrely colourful and sexually immoral life, see Sheridan Gilley, "Achilli, (Giovanni) Giacinto" (b.1803), Oxford Dictionary of National Biography, Oxford 2004 [http://www.oxforddnb.com/article/55519, accessed 4 January 2013]. Also State Gazette, 9 November 1849; Racine Daily Journal, 29 December 1859

${ }^{58}$ Trudel, Chiniquy relies on this document and, according to Laverdure, "Charles Chiniquy", 43-4, offers a mainly moral explanation of the pastor's flight from Rome. 
Sydney Smith, S.J., Pastor Chiniquy: An Examination of His "Fifty Years" in the Church of Rome" (London, c.1908), is the work in which his case against Chiniquy is made.

${ }^{59}$ Albany Evening Journal, 30 March 1864, p.6.

${ }^{60}$ Dundee Courier and Argus, 24 March 1866, p. 2; Liverpool Mercury, 24 March 1866, p.5; Derby Mercury, 28 March 1866, p.3.

${ }^{61}$ Manchester Times, 20 September 1862, p.2.

${ }^{62}$ Chiniquy, Priest, 9.

${ }^{63}$ Richard Hofstadter, The Paranoid Style in American Politics and Other Essays (New York: Knopf, 1965), 21.

${ }^{64}$ C. Chinquy, Fifty Years in the Church of Rome (London: Protestant Truth Society, 1948 edn), 16-19; discussed and contextualised in Verhoeven, “Harmful or benign?', xxyy.

${ }^{65}$ Chiniquy, Priest, 1.

${ }^{66}$ Belfast News-letter, 18 December 1861 [no page].

${ }^{67}$ Mary Ambrose, "Four Italian exiles in Edinburgh", in Bulletin of the Society for Italian Studies: A Journal for Teachers of Italian in Higher Education, 34 (2002): 8.

${ }^{68}$ Hall, "Gavazzi”, 313.

69 Chiniquy, Fifty Years, 75-81 (quotations, 75, 79).

${ }^{70}$ Donald M. MacRaild, Faith, Fraternity and Fighting: The Orange Order and Irish Migrants in Northern England, c.1850-1906 (Liverpool: Liverpool University Press, 2005), 191.

${ }^{71}$ Thames Advertiser, 6 January 1880, p.3.

${ }^{72}$ North Otago Times, 25 February 1880, p.2. 
${ }^{73}$ Salt Lake Weekly Tribune, 29 September 1892, p.1; Boston Journal, 7 December 1892, p.2; Salt Lake Weekly, 8 December 1892, p.1

${ }^{74}$ J.E. Handley, The Navvy in Scotland (Cork: Cork University Press, 1970), 269-70

75 John Bull, 24 March 1856, p.182.

${ }^{76}$ Billington, Protestant Crusade, 305-6.

${ }^{77}$ H.S. Diner, “"The most Irish city in the Union': the era of great migration', in R.H. Bayor and T.J. Meagher (eds.), The New York Irish (Baltimore, MD: Johns Hopkins University Press, 1996), 100.

${ }^{78}$ Chan, 39-50; John Bull, 22 March 1866, p.182.

79 John Bull, 7 June 1856, p.356.

${ }^{80}$ John Bull, 20 December 1856, p.812; Kenosha Tribune and Telegraph, 15 January 1857 [no page].

${ }^{81}$ Basil Hall, “Alessandro Gavazzi: A Barnabite Friar and the Risorgimento”, in D. Baker (ed), Church, Society and Politics: Papers Read at the Thirteenth Summer Meeting and the Fourteenth Winter Meeting of the Ecclesiastical History Society (Oxford: Basil Blackwell, 1975), 303-356.

${ }^{82}$ Church and State, 24 June 1853, p.391.

${ }^{83}$ New York Times, 10 June 1853, p.1; Chicago Tribune, 14 June 1853, p.2.

${ }^{84}$ New York Times, 14 June 1853, p.3.

${ }^{85}$ The Guardian, 29 June 1853, p.422.

${ }^{86}$ Morning Chronicle, 27 June 1854, p.9; The Guardian, 29 June 1853, p.422.

${ }^{87}$ Reported in the Colonial Times (Hobart), 29 October 1853, p.3, as a sign of the reach of the events and of the resulting opinion. 
${ }^{88}$ New York Daily Times, 14 June 1853, p.3.

${ }^{89}$ Church and State, 24 June 1853, p.391.

${ }^{90}$ New York Weekly Herald, 18 June 1853, p.2; New York Daily Times, 10 June 1853, p.1; Adams Sentinel, 20 June 1853, p.1.

${ }^{91}$ Reproduced widely, but see New York Times, 13 June 1853, p.3.

${ }^{92}$ Constitution (Middletown), 22 June 1853, p.1.

${ }^{93}$ Daily Placer Times and Transcript (San Francisco), 3 October 1853, p.3.

${ }^{94}$ Freeman's Journal, 27 August 1853, p5, 26 November 1853, p.6; Geelong Advertiser, 14 Stempber 1853, p.5; Launceston Examiner, 20 September 1853, p.5.

${ }^{95}$ David J. Endres, “Know Nothings, Nationhood, and the Nuncio: Reassessing the Visit of Archbishop Bedini”, US Catholic Historian, 21, 4 (2003), 1-16.

96 'Ugo Bassi and Bedini, letter from Gavazzi: New York Times, 27 August 1853, p.1

${ }^{97}$ New York Times, 31 December 1853, p.4, 2 January 1854, p.5. Quote from New York Times, 31 December 1854, p.8.

${ }^{98}$ Preston Guardian, 11 August 1855; Reynold's Newspaper, 19 August 1855.

${ }^{99}$ Lloyd's Weekly Newspaper, 4 April 1858.

${ }^{100}$ Daily News, 10 May 1858; Morning Chronicle, 11 May 1858.

101 The letter was probably sent by the Irishmen, since it had the same objective as the massing crowd. Moreover, threatening letters were part of the fabric of Irish sociopolitical relations. S.R. Gibbons, Captain Rock, Night Errant: The Threatening Letters of Pre-Famine Ireland, 1801-1845 (Dublin: Four Courts Press, 2004), introduction and passim.

${ }^{102}$ Quotation and detail from Hull Packet, 2 July 1858, p.7. 
${ }^{103}$ S. Gilley “The Garibaldi Riots of 1862”, Historical Journal, 16, 4 (1973): 697-732; F. Neal, "The Birkenhead Garibaldi riots of 1862", Transactions of the Historic Society of Lancashire and Cheshire, 131 (1982), 87-111.

${ }^{104}$ Belfast News-letter, 14 January 1862, p.3; Dublin Evening Mail, 10 January 1862, p.4, 14 January 1862, p.2.

105 Caledonian Mercury, 5 July 1862, p.6; Leeds Mercury, 3 July 1862, p.4.

${ }^{106}$ Birmingham Daily Post, 22 August 1862, p.2; Leeds Mercury, 21 August 1862, p. 3, 23 August 1862, p.5.

${ }^{107}$ Leeds Mercury, 9 September 1862, p.3, 15 September 1862, p.3; 16 September 1862, p.3, 22 September 1862, pp. 3, 4; London Standard, 10 September 1862, p.6; Liverpool Daily Post, 16 September 1862, p.7.

${ }^{108}$ London Standard, 5 December 1862, pp. 4, 6.

${ }^{109}$ New York Herald, 18 August 1871, p.4, New York Times, 18 August 1871, p.1, 20 August 1871, p.8.

${ }^{110}$ Jamestown Journal, 25 August 1873, p.2; St Alban's Daily Messenger, 19 August 1871, p.3.

${ }^{111}$ New York Evangelist, 25 February 1875, p.2

112 Stevens Point Journal (Indiana), 15 November 1884, p.2.

113 Scotsman, 12 March 1875, p.3.

${ }^{114}$ H.M. Curreen, "Pastor Charles Chiniquy: His New Zealand Tour of 1880", Unpublished MA thesis, University of Auckland, 1984, appendix 1, 62-4. Though not all Protestants in New Zealand were pleased to see him nor happy with his intemperate language. See Waikato Times, 21 February 1880, p.3. 
${ }^{115}$ Dollery, "Chiniquy", $123 \mathrm{ff}$.

${ }^{116}$ O'Brosnahan, passim; R.P. Davis, Irish Issues in New Zealand Politics, 1866-1922

(Dunedin: Otago University Press, 1974), 61; Curreen, "Pastor Charles Chiniquy", 11, 45-7, $60 \mathrm{ff}$.

${ }^{117}$ In1860 he was invited to a ceremony for laying the foundation stone of the Protestant Institution of Scotland in Edinburgh. Scotsman, 18 August 1860, p.4.

${ }^{118}$ New Zealand Tablet, 17 May 1900, p.2. 